\title{
ANTIBACTERIAL AND ANTIOXIDANT ACTIVITY OF LEUCAS ASPERA FLOWERS FROM BIHAR, INDIA
}

\author{
GULNAAZ SABRI, VIMALA Y*
}

Department of Microbiology and Food science and Technology, Gandhi Institute of Technology and Management Institute of science, GITAM University, Visakhapatnam, Andhra Pradesh, India. Email: vimalaulibala@gmail.com

Received: 12 August 2017, Revised and Accepted: 11 November 2017

\section{ABSTRACT}

Objective: The aim of this study was to explicate antibacterial, antifungal, and antioxidant activities of Leucas aspera flowers.

Methods: Antibacterial activity was done by agar diffusion method. The ethyl acetate extract of $L$. aspera flower was evaluated against both Grampositive and Gram-negative bacteria. Antifungal activity was also done by agar diffusion method. The agar used for antifungal activity was Czapek Dox Agar. Nitric oxide scavenging assay and free radical scavenging assay were used for the antioxidant activity. Griess reagent was used in nitric oxide scavenging assay. 1,1-diphenyl-2-picryl hydrazyl was used in free radical scavenging assay.

Results: L. aspera flower extract showed good antibacterial activity with the highest zone of inhibition against Vibrio cholera with 23 mm followed by Bacillus polymyxa showing $20 \mathrm{~mm}$ zone of inhibition. The ethyl acetate extract of $L$. aspera flower showed quite a good results with the highest inhibitory activity against Aspergillus niger with $13 \mathrm{~mm}$ zone of inhibition and lowest for Trichoderma viridae with $5 \mathrm{~mm}$ zone of inhibition. Antioxidant activity of $L$. aspera flower extract was done by free radical scavenging assay and nitric oxide scavenging assay. Nitric oxide scavenging assay showed prominent results almost performed equal to standard compound Butylated hydroxyl anisole (BHA) The values for $10 \mu$ l of $L$. aspera extract was 50.27 , for the standard (BHA) showed 50.81. L. aspera extract values for $50 \mu \mathrm{l}$ was 69.73 and for BHA, the values was 77.30 . For $100 \mu \mathrm{l}$, the extract gave 82.70 , and for standard BHA, the reading was 89.73 .

Conclusion: The results showed that L. aspera flower has broad-spectrum antibacterial activity ranging from 23 to $13 \mathrm{~mm}$ zone of inhibition. L. aspera flower has strong antioxidative power on nitric oxide radicals. The medicinal properties of plant species have made an outstanding contribution to the origin and evolution of many traditional herbal therapies.

Keywords: Leucas aspera flower, Antibacterial activity, Antifungal activity, Antioxidant activity.

(c) 2018 The Authors. Published by Innovare Academic Sciences Pvt Ltd. This is an open access article under the CC BY license (http://creativecommons. org/licenses/by/4. 0/) DOI: http://dx.doi.org/10.22159/ajpcr.2018.v11i2.21976

\section{INTRODUCTION}

Medicinal plants have shown a gilded source of antimicrobial agents. Plants are used in different countries and are a source of abounding potent and powerful drugs [1]. India has an extensive forest cover enriched with plant diversity [2]. Although hundreds of plant species have experimented for antimicrobial properties, there are many plants still not been evaluated [3]. Plants have the large-scale asset of being the most effective and cheaper alternative source of drugs [4]. In 2014, the World Health Organization gave its first report on surveillance of antimicrobial resistance, announcing that it is increasing global threat and scope to treat common nosocomial or community-acquired infection is at risk [5]. A vast variety of medicinal plants have been reported as an essential source of bioactive compounds [6]. The epidemiology of invasive infections has notably changed in the past 30 years. Hence, mycoses and bacterial infections are presently weighed as emerging diseases. This is an important area that needs the discovery of new and effective antimicrobial agents to gear antibiotic-resistant strains of pathogens [7]. Plants contain bioactive secondary metabolites with good potential to treat various diseases, and examples of some these compounds include terpenoids, alkaloids, phenols, unsaturated lactones, phenolic glycosides, saponins, sulfur compounds, cyanogenic glycosides, and glucosinolates [8,9]. Many pharmacognostical and pharmacological investigations are going on to identify new drugs for the development of novel therapeutic agents for the treatment of human diseases such as cancer and infectious diseases [10]. Leucas aspera is widely used to cure many diseased conditions, which connote that $L$. aspera has an infinite capacity for the discovery of new drugs. Leucas genus embraces 80 species [11]. L. aspera is an annual, branched, herb erecting to a height of 15-60 cm with stout and hispid acutely quadrangular stem and branches, and L. aspera flowers are white, sessile small, in dense terminal, or axillary whorls $[12,13]$.

\section{METHODS}

\section{Collection of $L$. aspera flowers}

Fresh $L$. aspera flowers used in this study were collected from Munger, Bihar, with latitude $25.3748^{\circ} \mathrm{N}$ and $86.4735^{\circ} \mathrm{E}$ longitude and was authenticated by Dr. S.B. Padal, the Department of Botany, Andhra University. Voucher specimen number-22230 and deposited in Botany Department Herbarium, Andhra University, India.

\section{Preparation of plant extracts}

Fresh L. aspera flowers were collected washed thoroughly with distilled water 2-3 times and shade dried. Dried flowers were powdered using electric pulverizers. $25 \mathrm{~g}$ of shade-dried L. aspera flowers was filled in thimble made of Whatman No 1 filter paper and extracted successively with ethyl acetate in Soxhlet extractor for $48 \mathrm{~h}$. The solvent was concentrated under reduced pressure at $40^{\circ}$ in a rotary evaporator and stored at $4^{\circ} \mathrm{C}$ in an airtight bottle until further use.

\section{Test cultures}

The cultures were obtained from microbial type culture collection (MTCC), Institute of Microbial Technology (IMTECH), Chandigarh.

- Test Bacteria: Bacteria used for this research are B. subtilis MTCC 736, Bacillus polymyxa (local isolate), Escherichia coli MTCC 723, B. pumilus MTCC 2466, and Vibrio cholerae MTCC 3906. These were maintained on nutrient agar slants. 
- Test fungi: Fungi used for my research are Aspergillus niger MTCC 1881, A. flavus MTCC 1883, Neurospora crassa MTCC 1855, and Trichoderma viride MTCC241.

\section{Antibacterial activity}

Antibacterial activity was performed by agar diffusion method [14]. The stock cultures of bacteria were revived by inoculating in nutrient broth media and grown at $37^{\circ} \mathrm{C}$ for $18 \mathrm{~h}$. The agar plates of the above media were prepared. Each plate was inoculated with $18 \mathrm{~h}$, old cultures $\left(100 \mu \mathrm{l}, 10^{-4}\right.$ colony-forming unit [CFU]), and spread evenly on the plate. After $20 \mathrm{~min}$, the wells of size $6 \mathrm{~mm}$ was punctured by sterile cork borer filled with 100 $\mu \mathrm{l}$ of $L$. aspera flower ethyl acetate extract, and ciprofloxacin antibiotic was used as positive control $(100 \mu \mathrm{g})$. All the plates were incubated at $37^{\circ} \mathrm{C}$ for $24 \mathrm{~h}$ and the diameter of inhibition zone was noted in $\mathrm{mm}$.

\section{Antifungal activity}

Antifungal activity was done by agar diffusion method [14]. Czapek Dox Agar media was used for the antifungal activity. The stock cultures were revived by inoculating in Czapek Dox Agar broth media and grown at $27^{\circ} \mathrm{C}$ for $48 \mathrm{~h}$. The agar plates of the above media were prepared. Each plate was inoculated with 48 -h-old cultures $\left(100 \mu \mathrm{l} 10^{-4} \mathrm{CFU}\right)$ and spread evenly on the plate. After $20 \mathrm{~min}$, the wells were punctured by sterile cork borer of $6 \mathrm{~mm}$ size and were filled with $100 \mu \mathrm{l}$ of L. aspera flower ethyl acetate extract. Fluconazole was used as a positive control. All the plates were incubated at $27^{\circ} \mathrm{C}$ for $96 \mathrm{~h}$, and the diameter of inhibition zone was noted in $\mathrm{mm}$.

\section{Antioxidant activity}

\section{Assay of free radical scavenging activity}

Free radical scavenging activity was done by the method which was expressed by the study of Braca et al. [15]. Different concentrations $(10 \mu \mathrm{l}, 50 \mu \mathrm{l}$, and $100 \mu \mathrm{l})$ of L. aspera flower extract in dimethyl sulfoxide were taken in a series of test tubes. The volume was adjusted to $500 \mu \mathrm{l}$ by adding methanol. $5 \mathrm{ml}$ of a $0.1 \mathrm{mM}$ methanolic solution of 1, 1-diphenyl-2-picryl hydrazyl (DPPH) (DPPH; from Sigma-Aldrich, Bengaluru) was added to these tubes and shaken vigorously. A control without the test compound but with an equivalent amount of methanol was maintained. The tubes were allowed to stand at RT for $20 \mathrm{~min}$. The absorbance of the L. aspera flower extract was measured at $517 \mathrm{~nm}$. Butylated hydroxyanisole (BHA) was used as reference standard. Free radical scavenging activity was calculated using the following formula:

\section{$\%$ radical scavenging activity $=($ control OD-sample OD $) \times 100$}

\section{Control OD}

\section{Assay of nitric oxide scavenging activity}

Nitric oxide scavenging assay was done by the method of Marcocci et al. [16]. The nitric oxide scavenging assay is done by Griess reagent. Antioxidant activity of $L$. aspera flower extract was evaluated by nitric oxide scavenging activity. Different concentrations $(10 \mu \mathrm{l}, 50 \mu \mathrm{l}$, and $100 \mu \mathrm{l})$ of $L$. aspera flower extract and BHA were taken in different test tubes and made up to $3 \mathrm{ml}$ with $0.1 \mathrm{M}$ phosphate buffer (potential of hydrogen $[\mathrm{pH}] \mathrm{7.2}$ ). Sodium nitroprusside $(5 \mathrm{mM})$ prepared in buffered saline ( $\mathrm{pH} 7.2)$ was added $(1 \mathrm{ml})$ to each tube. The reaction mixture was incubated for $30 \mathrm{~min}$ at room temperature. A control without the test sample but with an equivalent amount of methanol was maintained. After $30 \mathrm{~min}, 1.5 \mathrm{ml}$ of above solution was mixed with $1.5 \mathrm{ml}$ of Griess reagent (1\% sulfanilamide, $2 \%$ phosphoric acid, and $0.1 \% \mathrm{~N}-1$-naphthylethylenediamine dihydrochloride). The absorbance of the L. aspera flower extract was measured at $546 \mathrm{~nm}$. Nitric oxide radical scavenging activity was calculated using the following formula:

$$
\begin{aligned}
& \% \text { NO radical scavenging activity }= \\
& \frac{(\text { control optical density-sample OD }) \times 100}{\text { Control optical density }}
\end{aligned}
$$

\section{RESULTS}

The ability of $L$. aspera flower ethyl acetate extract to inhibit test bacteria was determined in this study. The result of antibacterial activity is summarized in Table 1. L. aspera flower extract showed good inhibitory activity against all the bacteria. The extract gave the highest zone of inhibition against $V$. cholera with $23 \mathrm{~mm}$ size of the zone of inhibition. B. polmyxa exhibited $20 \mathrm{~mm}$ zone of inhibition, followed by B. pumilus and E. coli. L. aspera flower extract showed least inhibitory activity against $E$. coli with only $13 \mathrm{~mm}$ zone of inhibition. Antifungal activity of L. aspera flower extract revealed good antifungal activity ranging from $13 \mathrm{~mm}$ to $5 \mathrm{~mm}$. The highest zone of inhibition was displayed by A. niger; whereas the lowest was shown by Trichoderma viridae as given in Table 2. L. aspera flower extract showed impressive antioxidant activity by nitric oxide scavenging assay, and it showed activity almost equal to standard compound BHA as depicted in Table 3. L. aspera flower extracts $10 \mu$ l showed the value of 50.27 with the standard of $10 \mu \mathrm{l}$ showing 50.81 . The extract of $50 \mu \mathrm{l}$ showed 69.73 as standard showing 77.30. The $100 \mu \mathrm{l}$ of $L$. aspera flower extracts showed 82.70 and standard BHA showing 89.73. L. aspera flower showed moderate antioxidant result by free radical scavenging assay as given in Table 4 . The $10 \mu \mathrm{l}$ of the flower extracts gave the reading 15.33 , whereas the standard displayed 54.27. The extracts of $50 \mu \mathrm{l}$ showed 30.69 as standard gave 70.10. The $100 \mu \mathrm{l}$ extracts showed 57.26 , whereas the standard BHA gave 91.82. Diffusion method is broadly used to explore the antimicrobial activity of natural substances and plant extracts. Discs or holes are used in this assay that contains solutions of the sample to be investigated [17]. The discovery of novel antimicrobial metabolites from medicinal plants is an important alternative to

Table 1: Antibacterial activity of $L$. aspera flower EA extracts

\begin{tabular}{ll}
\hline Microorganism & $\begin{array}{l}\text { L. aspera flower }(\mathrm{EA}) \text { extract zone } \\
\text { of inhibition in } \mathbf{~} \mathbf{m}(\mathbf{1 0 0} \boldsymbol{\mu l})\end{array}$ \\
\hline B. polymyxa & $20 \pm 3.61$ \\
B. megaterium & $17 \pm 2.0$ \\
B. pumilus & $16 \pm 1.73$ \\
E. coli & $13 \pm 2.65$ \\
V. cholera & $23 \pm 3.61$ \\
\hline
\end{tabular}

Values are mean inhibition zone $(\mathrm{mm}) \pm \mathrm{SD}$ of three replicates.

E. coli: Escherichia coli, L. aspera: Leucas aspera, B. polymyxa: Bacillus

polymyxa, B. megaterium: Bacillus megaterium, B. pumilus: Bacillus pumilus,

V. cholera: Vibrio cholera, EA: Ethyl acetate, SD: Standard deviation

Table 2: Antifungal activity of $L$. aspera flower EA extract

\begin{tabular}{ll}
\hline Microorganism & $\begin{array}{l}\text { L. aspera flower (EA) extract zone of } \\
\text { inhibition in } \mathbf{~ m m ~}(\mathbf{1 0 0} \boldsymbol{\mu l})\end{array}$ \\
\hline A. niger & $13 \pm 2.65$ \\
A. flavus & $6 \pm 1.73$ \\
Trichoderma viride & $5 \pm 2.0$ \\
Neurospora crassa & $7 \pm 2.65$ \\
\hline
\end{tabular}

Values are mean inhibition zone $(\mathrm{mm}) \pm \mathrm{SD}$ of three replicates.

A. niger: Aspergillus niger, A. flavus: Aspergillus flavus,

T. viride: Trichoderma viride, N. crassa: Neurospora crassa,

L. aspera: Leucas aspera, SD: Standard deviation, EA: Ethyl acetate

Table 3: \% nitric oxide scavenging activity of $L$. aspera flower EA extract

\begin{tabular}{lll}
\hline Concentration $(\mu \mathrm{l})$ & \multicolumn{2}{l}{ \% nitric oxide scavenging activity } \\
\cline { 2 - 3 } & $\begin{array}{l}\text { L. aspera flower (EA) } \\
\text { extract }\end{array}$ & BHA \\
\hline 10 & $50.27 \pm 0.072$ & $50.81 \pm 0.062$ \\
50 & $69.73 \pm 0.151$ & $77.30 \pm 0.458$ \\
100 & $82.70 \pm 0.062$ & $89.73 \pm 0.139$ \\
\hline
\end{tabular}

Values are \pm SD of three replicates. L. aspera: Leucas aspera, BHA: Butylated

hydroxy anisole, SD: Standard deviation, EA: Ethyl acetate 
Table 4: \% free radical scavenging activity of L. aspera flower EA extract

\begin{tabular}{lll}
\hline Concentration $(\mu \mathrm{l})$ & \multicolumn{2}{l}{ \% free radical scavenging activity } \\
\cline { 2 - 3 } & $\begin{array}{l}\text { L. } \text { aspera flower }(\mathrm{EA}) \\
\text { extract }\end{array}$ & BHA \\
\hline 10 & $15.33 \pm 0.096$ & $54.27 \pm 0.125$ \\
50 & $30.69 \pm 0.082$ & $70.10 \pm 1.153$ \\
100 & $57.26 \pm 0.079$ & $91.82 \pm 0.062$ \\
\hline
\end{tabular}

Values are \pm SD of three replicates. L. aspera: Leucas aspera, BHA: Butylated

hydroxy anisole, SD: Standard deviation, EA: Ethyl acetate

overcome the increasing levels of drug resistance by human pathogens. Novel antimicrobial substance from medicinal plants is a substitute to overthrown the increasing levels of drug resistance by human pathogens. New antibiotics and chemotherapeutic agents research is increasing in the chemistry of medicinal plants [18].

Medicinal plants are an important source of antioxidants [19]. Natural antioxidants increase the antioxidant capacity of the plasma and reduce the risk of certain diseases. Antioxidant activity of the plasma is increased by natural antioxidants that help in reducing the danger if diseases [20].

\section{DISCUSSION}

About $80 \%$ of the world's population uses traditional herbal medicine for their primary health care [21]. L. aspera plants were evaluated for antimicrobial and antioxidant activitises. This study aimed to regulate the antibacterial activity of five selected bacteria. V. cholera showed the highest zone of inhibition with $23 \mathrm{~mm}$. B. polymyxa showed $20 \mathrm{~mm}$ zone of inhibition. Antibacterial activity of L. aspera root, flower, leaf, and stem showed good antibacterial activity against Staphylococcus aureus, E. coli, Pseudomonas aeruginosa, S. typhimurium, S. choleraesuis, and Shigella flexneri by Chew et al. in 2012 [22]. L. aspera flower in this study showed satisfying antifungal activity. A. niger displayed apical zone of inhibition with $13 \mathrm{~mm}$. L. aspera flower showed the lowest zone of inhibition for T. viridae with only $5 \mathrm{~mm}$. Tahareen et al. in 2016 studied antibacterial activity on L. aspera leaves showed that E. coli was inhibited at all concentrations, followed by Klebsiella and Pseudomonas [23]. Gowrish et al. in 2016 studied antibacterial activity of L. marrubioides, the results depicted that pet ether extract was very much effective against Gram-positive bacteria B. cereus, S. Pyogenes, and B. subtilis and Gram-negative bacteria Proteus mirabilis, Klebsiella pneumoniae, andV. cholerae [24]. In 1987, Thakur studied antifungal activity of L. aspera ethanol and chloroform extracts against Trichophyton and Microsporum, the plant reported having fungicidal and fungistatic activity. L. aspera flower extract showed highly impressive antioxidant activity by ferric radical scavenging activity and nitric oxide scavenging assay. In 2016, Tahareen et al. performed antioxidant activity of $L$. aspera, and $L$. Aspera $(40 \%)$ exhibited maximum DPPH radical scavenging activity which was found to be $80.69 \pm 3.68$ [23]. In 2007, Rahman et al. studied antioxidant activity of ethanolic extracts of $L$. aspera root and exhibited high free radical scavenging assay [25]. Increased bacterial strains to variety of antimicrobial agents have demanded new antibacterial agents effective against pathogenic bacteria [26]

\section{CONCLUSION}

In the present study, L. aspera flowers have shown broad-spectrum antibacterial activity and antifungal activity. The flowers can be used as natural medicine in the treatment of various infectious diseases that are caused by fungi and bacteria. The flowers also gave incredible antioxidant activity by nitric oxide scavenging assay. Infectious diseases are the second leading cause of death. Antibiotics are used continuously, due to this microorganism has become resistant. Antibiotics also show a lot of side effects that have an adverse effect on human beings, so the medicinal plant can be used and explored in great amount for treatment of infectious diseases.

\section{ACKNOWLEDGMENT}

The authors are thankful to University Grants Commission-Maulana Azad National Fellowship for providing financial support and Department of Microbiology, GITAM University for providing laboratory facilities.

\section{AUTHORS CONTRIBUTION}

Gulnaaz sabri performed the experimentation as part of her Ph.D. Gulnaaz sabri and Y.Vimala prepared the manuscript, Y.Vimala supervised the work, evaluated the data and corrected the manuscript for publication. All authors read and approved the final manuscript.

\section{CONFLICT OF INTEREST}

We declare we have no conflict of interest.

\section{REFERENCES}

1. Srivastava J, Lambert J, Vietmeyer N. Antimicrobial Activity of Anogeissus latifolia. Medicinal plants: An Expanding Role in Development. World Bank Technical Paper. No.320. 106. Journal of Ethnopharmacology; 1996. p. 57-61.

2. Parekh J, Chanda S. In vitro antifungal activity of methanol extracts of some Indian medicinal plants against pathogenic yeast and moulds. Afr J Biotechnol 2008;7:4349-53.

3. Balandrin MF, Klocke JA, Wurtele ES, Bollinger WH. Natural plant chemicals: Sources of industrial and medicinal materials. Science 1985;228:1154-60

4. van der Watt E, Pretorius JC. Purification and identification of active antibacterial components in Carpobrotus edulis L. J Ethnopharmacol 2001;76:87-91

5. World Health Organization. Antimicrobial Resistance: Global Report on Surveillance 2014. Geneva: World Health Organization; 2014.

6. Balunas MJ, Kinghorn AD. Drug discovery from medicinal plants. Life Sci 2005;78:431-41

7. Rapp RP. Changing strategies for the management of invasive fungal infections. Pharmacotherapy 2004;24:4S-28S

8. Mukherjee AK, Basu S, Sarkar N, Ghosh AC. Advances in cancer therapy with plant based natural products. Curr Med Chem 2001;8:146786.

9. Quiroga EN, Sampietro AR, Vattuone MA. Screening antifungal activities of selected medicinal plants. J Ethnopharmacol 2001;74:89-96.

10. Newman DJ, Cragg GM, Snader KM. Natural products as sources of new drugs over the period 1981-2002. J Nat Prod 2003;66:1022-37.

11. Hedge IC. Labiatae. In: Ali SI, Nasir YJ, editors. Flora of Pakistan. Karachi: University of Karachi Department of Botany; 1990. p. 192.

12. Kirtikar KR, Basu BD. Indian Medicinal Plants. New Delhi: Periodical Experts; 1975. p. 2019-20.

13. Hooker JD. The Flora of British India. London: The Muston Company; 1984. p. 690.

14. Rios JL, Recio MC, Villar A. Screening methods for natural products with antimicrobial activity: A review of the literature. J Ethnopharmacol 1988;23:127-49.

15. Braca A, De Tommasi N, Di Bari L, Pizza C, Politi M, Morelli I, et al. Antioxidant principles from Bauhinia tarapotensis. J Nat Prod 2001;64:892-5

16. Marcocci L, Maguire JJ, Droy-Lefaix MT, Packer L. The nitric oxidescavenging properties of Ginkgo biloba extract EGb 761. Biochem Biophys Res Commun 1994;201:748-55.

17. Rauha JP, Remes S, Heinonen M, Hopia A, Kähkönen M, Kujala T, et al. Antimicrobial effects of finnish plant extracts containing flavonoids and other phenolic compounds. Int J Food Microbiol 2000;56:3-12.

18. Zaika LL. Spices and herbs: Their antimicrobial activity and its determination. J Food Saf 1988;9:97-118.

19. Rice-Evans C. Flavonoids and isoflavones: Absorption, metabolism, and bioactivity. Free Radic Biol Med 2004;36:827-8.

20. Prior RL, Cao G. Antioxidant phytochemicals in fruits and vegetables: Diet and health implications. Hort Science 2000;35:588-92.

21. Vijayan A, Liju VB, John JV, Reena B, Parthipan RC. Traditional remedies of Kani tribes of Kottoor reserve forest, Agasthyavanam, Thiruvananthapuram, Kerala Indian J Tradit Knowledge 2007;6:589-94.

22. Chew AL, Jessica JJ, Sasidharan S. Antioxidant and antibacterial activity of different parts of Leucas aspera. Asian Pac J Trop Biomed 2012;2:176-80. 
23. Tahareen S, Shwetha R, Myrene RD. Potential antioxidant, antiinflammatory and antibacterial evaluation of extracts of Leucas aspera using in vitro models. Int J Pharm Pharm Sci 2016;8:292-7.

24. Gowrish A, Vagdevi HM, Rajashekar H. Phytochemical screening and antimicrobial activity of Leucas marrubioides desf. Root extracts. Int J Pharm Pharm Sci 2016;8:209-12.
25. Rahman MS, Sadhu SK, Hasan CM. Preliminary antinociceptive, antioxidant and cytotoxic activities of Leucas aspera root. Fitoterapia 2007;78:552-5

26. Salman MT, Khan RA, Shukla I. Antimicrobial activity of Nigella sativa Linn. Seed oil against multi-drug resistant bacteria from clinical isolates. Nat Prod Radiance 2008;7:10-1. 